\title{
Gallium(III) Nitrate Inhibits Pathogenic Vibrio splendidus Vs by Interfering with the Iron Uptake Pathway
}

\author{
Tongxiang Song, Xuelin Zhao, Yina Shao, Ming Guo, Chenghua Li, and Weiwei Zhang* \\ School of Marine Sciences, Ningbo University, Ningbo 315211, P.R. China
}

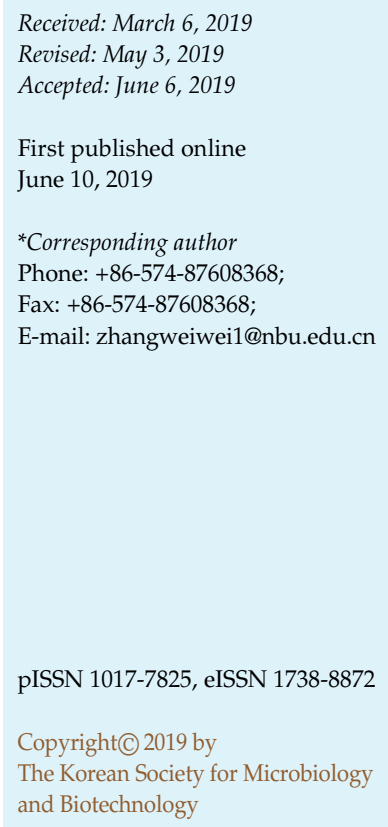

\begin{abstract}
It is well known that iron is critical for bacterial growth and pathogenic virulence. Due to chemical similarity, $\mathrm{Ga}^{3+}$ competes with $\mathrm{Fe}^{3+}$ for binding to compounds that usually bind $\mathrm{Fe}^{3+}$, thereby interfering with various essential biological reactions. In our present study, gallium(III) nitrate $\left[\mathrm{Ga}\left(\mathrm{NO}_{3}\right)_{3}\right]$ could repress the growth of $V$. splendidus Vs without complete inhibition. In the presence of $\mathrm{Ga}\left(\mathrm{NO}_{3}\right)_{3}$, the secretion of homogentisic acid-melanin (HGAmelanin) in $V$. splendidus Vs cells could be increased by 4.8 -fold, compared to that in the absence of $\mathrm{Ga}\left(\mathrm{NO}_{3}\right)_{3}$. HGA-melanin possessed the ability to reduce $\mathrm{Fe}^{3+}$ to $\mathrm{Fe}^{2+}$. In addition, HGA-melanin increased the mRNA levels of $f e o A$ and $f e o B$, genes coding $\mathrm{Fe}^{2+}$ transport system proteins to 1.86- and 6.1-fold, respectively, and promoted bacterial growth to $139.2 \%$. Similarly, the mRNA expression of $f e o A$ and $f e o B$ was upregulated 4.11-fold and 2.71-fold in the presence of $640 \mu \mathrm{M} \mathrm{Ga}\left(\mathrm{NO}_{3}\right)_{3}$, respectively. In conclusion, our study suggested that although $\mathrm{Ga}\left(\mathrm{NO}_{3}\right)_{3}$ could interfere with the growth of $V$. splendidus Vs, it could also stimulate both the production of $\mathrm{Fe}^{3+}$-reducing HGA-melanin and the expression of $f e o A$ and $f e o B$, which facilitate $\mathrm{Fe}^{2+}$ transport in V. splendidus Vs.
\end{abstract}

Keywords: Vibrio splendidus $\mathrm{Vs}, \mathrm{Ga}\left(\mathrm{NO}_{3}\right)_{3}$ inhibition, iron uptake, HGA-melanin-mediated $\mathrm{Fe}^{2+}$ uptake

\section{Introduction}

In recent years, aquaculture of the sea cucumber, Apostichopus japonicus (Echinodermata: Holothuroidea), has developed rapidly and become an important part of the aquaculture industry in China [1]. However, with the rapid expansion of scale, a variety of diseases, for example, a typical skin ulcer syndrome (SUS), have emerged and hindered the healthy and sustainable aquaculture of A. japonicus [2]. Vibrio splendidus is one of the most important opportunistic pathogens that can infect $A$. japonicus, leading to outbreaks of SUS [3]. Thus, study of the pathogenic metabolic processes of $V$. splendidus is recommended to control this pathogen.

It is well known that iron is a critical element for bacterial growth [4], intracellular replication [5], and virulence [6]. However, the concentration of bio-available iron is usually lower than $10^{-18} \mathrm{M}$, a level far below what is needed for optimal bacterial growth [7]. Thus, bacteria have evolved several strategies to compete for iron from extremely insoluble ferric oxyhydroxide polymers in the natural environment or from iron-protein complexes such as transferrin or lactoferrin in host tissues $[8,9]$. The most common iron uptake pathways used by bacteria include those involving ferric complexes (e.g., ferri-siderophores, haem and haem-protein complexes, ferric-transferrin/ lactoferrin complexes, and ferric-citrate). In addition to directly transporting $\mathrm{Fe}^{3+}$, bacteria can also reduce $\mathrm{Fe}^{3+}$ to $\mathrm{Fe}^{2+}$ in the extracellular space and then transport $\mathrm{Fe}^{2+}$ into the intracellular space [10]. In Legionella pneumophila, homogentisic acid-melanin (HGA-melanin) was secreted to reduce $\mathrm{Fe}^{3+}$ to $\mathrm{Fe}^{2+}$, and then $\mathrm{Fe}^{2+}$ was transferred into the intracellular space by the inner membrane protein FeoB $[11,12]$. In previous studies, the iron uptake process had been shown to be associated with the pathogenesis of $V$. splendidus [13], and V. splendidus was able to acquire iron through the hydroxamate siderophore-IutA receptor iron acquisition pathway under conditions of low iron bio- 
availability [14]. Thus, we wondered whether the infectivity of $V$. splendidus can be attenuated by interfering with its iron uptake process.

$\mathrm{Ga}^{3+}$ has an ionic radius and binding propensities very similar to those of $\mathrm{Fe}^{3+}$, and it can function as an iron analog [15]. Therefore, $\mathrm{Ga}^{3+}$ can bind to compounds that bind $\mathrm{Fe}^{3+}$, such as siderophore [16] and heme [17] transport systems for $\mathrm{Fe}^{3+}$ uptake, leading to the uptake of $\mathrm{Ga}^{3+}$ instead of $\mathrm{Fe}^{3+}$ [18]. This is called the 'Trojan horse' strategy, and in these cases, Ga-based compounds can be used as anti-infective agents. Simple gallium salts such as gallium nitrate $\left[\mathrm{Ga}\left(\mathrm{NO}_{3}\right)_{3}\right][19]$ and gallium maltolate [20] have been determined to exhibit antibacterial activity, and they represent a new class of anti-infective agents that are different from antibiotics [21].

In this study, the effects of $\mathrm{Ga}\left(\mathrm{NO}_{3}\right)_{3}$ on the growth and iron uptake pathways of $V$. splendidus Vs were determined. Since $\mathrm{Ga}\left(\mathrm{NO}_{3}\right)_{3}$ did not exhibit a strong inhibitory effect on $V$. splendidus $\mathrm{Vs}$, we determined the effects of $\mathrm{Ga}\left(\mathrm{NO}_{3}\right)_{3}$ on the other iron uptake pathways in V. splendidus Vs. Based on the data obtained, the action mode of $\mathrm{Ga}\left(\mathrm{NO}_{3}\right)_{3}$ on the growth and the iron uptake of $V$. splendidus Vs was proposed.

\section{Materials and Methods}

\section{Bacterial Strains, Culture Conditions, and Chemicals}

The $V$. splendidus $\mathrm{Vs}$ used in this study was isolated from diseased A. japonicus, and its pathogenicity had been determined in our previous study [13]. $V$. splendidus Vs was cultured at $28^{\circ} \mathrm{C}$ in $2216 \mathrm{E}$ media consisting of $5 \mathrm{~g} / 1$ tryptone, $1 \mathrm{~g} / 1$ yeast extract and $0.01 \mathrm{~g} / 1 \mathrm{FePO}_{4}$ in aged seawater. When needed, 2,2'-dipyridyl (Aladdin, Shanghai, China), 8-hydroxyquinoline (Aladdin) or gallium(III) nitrate $\left[\mathrm{Ga}\left(\mathrm{NO}_{3}\right)_{3}\right]$ was separately added into the media. Gallium(III) nitrate hydrate $\left[\mathrm{Ga}\left(\mathrm{NO}_{3}\right)_{3} \cdot \mathrm{xH}_{2} \mathrm{O}\right]$ was purchased from Sigma-Aldrich (Shanghai, China). The chemicals 2,2'dipyridyl, iron (III) chloride hexahydrate, chromeazurol (CAS), hexadecyl trimethyl ammonium bromide (HTDMA), piperazine, sodium molybdate shuttle solution, ferric chloride, iron phosphate, vitamin $\mathrm{C}$ and hydroxylamine hydrochloride were all purchased from Aladdin China). Unless otherwise stated, all other chemicals used in this study were purchased from Sangon (China).

Inhibitory Effect of $\mathrm{Ga}\left(\mathrm{NO}_{3}\right)_{3}$ on the Growth of V. splendidus Vs

The ability of $V$. splendidus $\mathrm{Vs}$ to grow in $2216 \mathrm{E}$ media supplemented with different concentrations of $\mathrm{Ga}\left(\mathrm{NO}_{3}\right)_{3}$ was determined. $V$. splendidus $\mathrm{Vs}$ at an initial concentration of $6.0 \times$ $10^{6} \mathrm{CFU} / \mathrm{ml}$ was inoculated into 2216E media supplemented with $\mathrm{Ga}\left(\mathrm{NO}_{3}\right)_{3}$ at concentrations of $20,40,80,160,320,640$, or $1,280 \mu \mathrm{M}$. $V$. splendidus Vs grown in $2216 \mathrm{E}$ media without $\mathrm{Ga}\left(\mathrm{NO}_{3}\right)_{3}$ was used as a control. The growth of $V$. splendidus Vs was monitored at different time intervals, and $1 \mathrm{ml}$ of each culture was taken to measure the $\mathrm{OD}_{600}$ in a microplate reader (Molecular Devices, Shanghai, China) after culture for $0,6,12,24,36,48,60,72,84$, or $96 \mathrm{~h}$, respectively. The inhibitory activity of $\mathrm{Ga}\left(\mathrm{NO}_{3}\right)_{3}$ was determined using the following equation: inhibitory activity $\%=$ $\left(C_{0}-C\right) / C_{0} \times 100$, where $C_{0}$ is the $=\mathrm{OD}_{600}$ of $V$. splendidus $V s$ cultured in $2216 \mathrm{E}$ media without $\mathrm{Ga}\left(\mathrm{NO}_{3}\right)_{3}$, and $\mathrm{C}$ is the $=\mathrm{OD}_{600}$ of $V$. splendidus Vs cultured in 2216E media with different concentrations of $\mathrm{Ga}\left(\mathrm{NO}_{3}\right)_{3}$. The inhibitory effect of $\mathrm{Ga}\left(\mathrm{NO}_{3}\right)_{3}$ on $V$. splendidus Vs was also tested in natural seawater. Cell-free seawater was obtained by filtration through a $0.22-\mu \mathrm{m}$ polycarbonate membrane filter (Millipore). An overnight culture of $V$. splendidus Vs was washed three times with cell-free seawater, and the cell density was adjusted to $1.0 \times 10^{8} \mathrm{CFU} / \mathrm{mL}$ based on the $\mathrm{OD}_{600}$ determined using a UV-Vis spectrophotometer (Thermo Fisher, USA). The $V$. splendidus $\mathrm{Vs}$ suspension was then divided into eight parts, seven of which were separately supplemented with 20, 40, 80, 160, 320,640 , or $1,280 \mu \mathrm{M} \mathrm{Ga}\left(\mathrm{NO}_{3}\right)_{3}$, while the suspension without $\mathrm{Ga}\left(\mathrm{NO}_{3}\right)_{3}$ was used as a control. All eight groups were incubated at $28^{\circ} \mathrm{C}$ for $96 \mathrm{~h}$, and then the cultures were diluted and spread on solid 2216E media. The bacterial colonies were counted after being incubated for $24 \mathrm{~h}$. The inhibitory activity of $\mathrm{Ga}\left(\mathrm{NO}_{3}\right)_{3}$ was determined using the equation mentioned above.

\section{Siderophore Quantification}

The siderophores produced by $V$. splendidus Vs and determined in the presence of $0,20,40,80$, or $160 \mu \mathrm{M} 2,2^{\prime}$-dipyridyl or $\mathrm{Ga}\left(\mathrm{NO}_{3}\right)_{3}$ were quantified using a method adapted from Schwyn and Neilands [22]. Briefly, V. splendidus Vs was incubated in $2216 \mathrm{E}$ media supplemented with $2,2^{\prime}$-dipyridyl or $\mathrm{Ga}\left(\mathrm{NO}_{3}\right)_{3}$ for $48 \mathrm{~h}$, and the supernatants were obtained by centrifuging the samples at $10,000 \times g$ for $10 \mathrm{~min}$. A volume of $1 \mathrm{ml}$ of cell-free supernatant from each culture was mixed with $1 \mathrm{ml}$ of CAS bright blue dye and $20 \mu \mathrm{l}$ of shuttle solution. Samples of 2216E media supplemented with various concentrations of 2,2'-dipyridyl or $\mathrm{Ga}\left(\mathrm{NO}_{3}\right)_{3}$ were also mixed with CAS and shuttle solution as the reference samples. The mixtures were kept at room temperature for $5 \mathrm{~min}$, and then the $\mathrm{OD}_{630}$ values were measured in a microplate reader. The relative quantities of siderophores were determined from the following equation: siderophore $\%=(\mathrm{Ar}-\mathrm{As}) / \mathrm{Ar} \times 100$, where $\mathrm{Ar}$ is the $=$ reference absorbance and $\mathrm{As}$ is the = sample absorbance [23].

\section{Measurement of HGA-Melanin and Determination of HGA- Melanin Production by Vibrio splendidus Vs}

To determine the maximum absorbance value of HGA-melanin, a method adapted from [24] was used. Briefly, supernatants were obtained and measured for their absorbance using a NanoDrop 2000 UV-Vis spectrophotometer (Thermo Fisher Scientific, USA). HGA-melanin made as described by Zheng et al. [12] was used as a positive control. Briefly, $200 \mu \mathrm{g} / \mathrm{ml}$ monomeric HGA in PBS was incubated at $37^{\circ} \mathrm{C}$ with agitation at $180 \mathrm{rpm}$ for $72 \mathrm{~h}$. To collect the natural HGA-melanin produced by $V$. splendidus Vs, 
$1.0 \times 10^{7} \mathrm{CFU} / \mathrm{ml} \mathrm{V}$. splendidus Vs was inoculated into $2216 \mathrm{E}$ media and grown for $72 \mathrm{~h}$. The cell-free supernatant was then acidified to $\mathrm{pH}$ 2.0-3.0 using $\mathrm{HCl}$. HGA-melanin was collected by centrifugation at 7,200 $\times g$ for $20 \mathrm{~min}$ after precipitation for $30 \mathrm{~min}$, and the precipitate was soaked in $6 \mathrm{M} \mathrm{HCl}$ for $4 \mathrm{~h}$. Then, the precipitate was washed twice in ethyl alcohol and once in acetone. The final precipitate was dried at $60^{\circ} \mathrm{C}$ and dissolved with $1 \mathrm{M}$ $\mathrm{NaOH}$. Finally, the extracted HGA-melanin was adjusted to $\mathrm{pH}$ 7.0, and adjusted again to the same concentration as the synthetic HGA-melanin using a NanoDrop 2000 UV-Vis spectrophotometer.

To detect HGA-melanin production by $V$. splendidus $V s$ at different growth phases, an overnight culture of $V$. splendidus Vs was used to incubate 2216E media containing $1.0 \mathrm{~g} / \mathrm{ml}$ L-tyrosine at an inoculation volume of $1 \%$ and aliquots were taken for measurement of the $\mathrm{OD}_{600}$ values in a microplate reader at $12-\mathrm{h}$ intervals for a total incubation period of $96 \mathrm{~h}$. The HGA-melanin in the cell-free supernatant was monitored according to the maximum absorbance value obtained from spectroscopic analysis of the synthetic HGA-melanin. To detect HGA-melanin production by $V$. splendidus Vs in the presence of $\mathrm{Ga}\left(\mathrm{NO}_{3}\right)_{3}$, overnight cultures of $V$. splendidus Vs were inoculated at $1 \%$ volume into $2216 \mathrm{E}$ media supplemented with 320,640 , or $1,280 \mu \mathrm{M} \mathrm{Ga}\left(\mathrm{NO}_{3}\right)_{3}$. V. splendidus Vs grown in $2216 \mathrm{E}$ media without $\mathrm{Ga}\left(\mathrm{NO}_{3}\right)_{3}$ was used as a control. Then, the production of HGA-melanin was monitored as described above.

\section{$\mathrm{Fe}^{3+}$ Reduction Assay}

The reduction of $\mathrm{Fe}^{3+}$ by HGA-melanin was measured as described by Chatfield and Cianciotto [25]. Briefly, $400 \mu \mathrm{M}$ ferrozine, $120 \mu \mathrm{M} \mathrm{FeCl}_{3}$ and $120 \mu \mathrm{M} \mathrm{FePO}_{4}$ in $250 \mu \mathrm{l}$ Tris buffer $(25 \mathrm{mM}, \mathrm{pH} 7.5)$ were mixed. Then, $10 \mu \mathrm{l}$ of synthetic HGAmelanin, $10 \mu \mathrm{l}$ of monomeric HGA $(200 \mu \mathrm{g} / \mathrm{ml})$, or $100 \mu \mathrm{l}$ of bacterial HGA-melanin was added into each of the above mixtures, respectively. PBS solvent was used as a negative control for monomeric HGA and synthetic HGA-melanin, and $1 \mathrm{M} \mathrm{NaOH}$ ( $\mathrm{pH}$ 7.0) was used as a negative control for the extracted HGAmelanin. Vitamin $\mathrm{C}$ and $1 \mathrm{mM}$ hydroxylamine hydrochloride, which have defined $\mathrm{Fe}^{3+}$ reduction activity, were used as positive controls. The reactions were kept at room temperature for $12 \mathrm{~h}$. The developed color was measured at $560 \mathrm{~nm}$ using a microplate reader (Molecular Devices, China).

\section{Effects of HGA and HGA-Melanin on the Growth of $V$. splendidus Vs}

V. splendidus Vs was precultured in 2216E media without $66.3 \mu \mathrm{M}$ $\mathrm{FePO}_{4}$ to the mid-logarithmic phase and then inoculated into $2216 \mathrm{E}$ media that was supplemented with $344.4 \mu \mathrm{M}$ 8-hydroxyquinoline and grown to an $\mathrm{OD}_{600}$ of 0.15 . A total of $200 \mu \mathrm{l}$ of the bacterial suspension was inoculated into the wells of a 96-well microtiter plate. Ten microliters of $2216 \mathrm{E}$ media with or without $66.3 \mu \mathrm{M}$ $\mathrm{FePO}_{4}, 2216 \mathrm{E}$ with $344.4 \mu \mathrm{M}$ 8-hydroxyquinoline, HGA, HGAmelanin or PBS solvent was also added into the wells. The inoculated plates were then incubated at $28^{\circ} \mathrm{C}$ for $60 \mathrm{~h}$. Then, the
$\mathrm{OD}_{600}$ of each well was recorded every $12 \mathrm{~h}$. To prevent condensation, the lids of the microtiter plates were precoated with $10 \mathrm{ml}$ of $0.05 \%$ Triton X-100 in 20\% ethanol for $0.5 \mathrm{~h}$ and air dried [26].

\section{Sample Collection for Real-Time Reverse Transcription PCR (RT-PCR)}

To determine the effects of 2,2'-dipyridyl or $\mathrm{Ga}\left(\mathrm{NO}_{3}\right)_{3}$ on the expression of iutA, $V$. splendidus Vs was grown in $2216 \mathrm{E}$ media without $66.3 \mu \mathrm{M} \mathrm{FePO}_{4}$ at $28^{\circ} \mathrm{C}$ to an $\mathrm{OD}_{600}$ of approximately 0.2 . Then, the culture was divided into three parts. Two of the parts were supplemented with $80 \mu \mathrm{M} 2$, 2'-dipyridyl or $\mathrm{Ga}\left(\mathrm{NO}_{3}\right)_{3}$, and the third part was left unsupplemented and used as a control. After incubation at $28^{\circ} \mathrm{C}$ for $6 \mathrm{~h}, 12 \mathrm{~h}$, and $24 \mathrm{~h}, 2 \mathrm{ml}$ of culture was taken, and the cell pellets were collected.

To determine the effects of HGA-melanin on the expression of $f e o A$ and $f e o B, V$. splendidus Vs was grown in 2216E media without $66.3 \mu \mathrm{M} \mathrm{FePO}$ until the mid-logarithmic phase. Then, the cells were washed three times with $2216 \mathrm{E}$ media supplemented with $344.4 \mu \mathrm{M}$ 8-hydroxyquinoline and then resuspended to an $\mathrm{OD}_{600}$ of 0.15 . The resuspended $V$. splendidus Vs was divided into two parts. One part was supplemented with $100 \mu$ l of HGA-melanin, and the other part was supplemented with an equal volume of PBS as a control group. After incubation at $28^{\circ} \mathrm{C}$ for $10 \mathrm{~min}$, $30 \mathrm{~min}, 60 \mathrm{~min}, 12 \mathrm{~h}$, and $24 \mathrm{~h}, 2 \mathrm{ml}$ of culture was taken and the cell pellets were collected.

To determine the effects of $\mathrm{Ga}\left(\mathrm{NO}_{3}\right)_{3}$ on the expression of iutA, $f e o A$ and $f e o B, V$. splendidus Vs was grown in 2216E media without $66.3 \mu \mathrm{M} \mathrm{FePO}_{4}$ at $28^{\circ} \mathrm{C}$ to an $\mathrm{OD}_{600}$ of approximately 0.2 . Then the culture was divided into two parts. One was supplemented with $640 \mu \mathrm{M} \mathrm{Ga}\left(\mathrm{NO}_{3}\right)_{3}$, and the other sample was left untreated and used as a control. After inoculation at $28^{\circ} \mathrm{C}$ for $10 \mathrm{~min}, 30 \mathrm{~min}$, $60 \mathrm{~min}, 12 \mathrm{~h}$, and $24 \mathrm{~h}, 2 \mathrm{ml}$ of culture was taken and the cell pellets were collected.

\section{Real-Time RT-PCR}

RNA was extracted from $V$. splendidus Vs cells that were collected at different time points using a Bacterial RNA Isolation Kit (Omega). Then, $1 \mu \mathrm{g}$ of RNA was reverse transcribed into cDNA using PrimeScript reverse transcriptase (Takara). Real-time RT-PCR was carried out using SYBR Premix Ex Taq (Takara) in an ABI 7500 real-time detection system (Applied Biosystems) as described previously [27]. Each assay was performed in triplicate using $16 \mathrm{~S}$ rRNA as a reference control. Primers were designed according to the genomic sequence of $V$. splendidus $\mathrm{Vs}$ and their nucleotide sequences are shown in Table 1. Dissociation analysis of the amplification products was performed at the end of each PCR run to confirm that only one PCR product was amplified and detected. The comparative threshold cycle method $\left(2^{-\Delta \Lambda C T}\right.$ method) was used to analyze the mRNA levels.

\section{Accession Numbers of the Bacterial Strains, Database Search and Statistical Analysis}

The isolate of $V$. splendidus Vs has been deposited into the China 
Table 1. Primers used in this study.

\begin{tabular}{ll}
\hline Primer name & \multicolumn{1}{c}{ Nucleotide sequence $\left(5^{\prime} \rightarrow 3^{\prime}\right)$} \\
\hline 933F & GCACAAGCGGTGGAGCATGTGG \\
16SRTR1 & CGTGTGTAGCCCTGGTCGTA \\
IutA $^{1} \mathrm{~F}$ & GTACGATCTACCACCTCAC \\
IutAR & CGTAGTATTTCGCAGGGTC \\
FeoA ${ }^{2} \mathrm{~F}$ & TCTCACAACTAGAGCAAGGC \\
FeoAR & CGGCGAATCAACGTCACC \\
FeoB ${ }^{3} \mathrm{~F}$ & GCACTAATCCCTTCTGTTG \\
FeoBR & TTGAATGCGAGGCTGAGGA \\
\hline
\end{tabular}

${ }^{1}$ IutA is an abbreviation for the name of the protein of aerobactin siderophore receptor IutA.

${ }^{2} \mathrm{FeoA}$ is an abbreviation for the name of the protein of the Ferrous iron transport A. ${ }^{3} \mathrm{FeoB}$ is an abbreviation for the name of the protein of Ferrous iron transport $\mathrm{B}$.

General Microbiological Culture Collection (CGMCC, China) with accession numbers 7.242. Statistical significance was determined by one-way analysis of variance (ANOVA). Statistical analyses were performed using two-tailed Student's $t$ tests. In all cases, the significance levels were defined as ${ }^{*} p<0.05,{ }^{* *} p<0.01$ and ${ }^{* * *} p<$ 0.001 .

\section{Results}

Only Higher Concentrations of $\mathrm{Ga}\left(\mathrm{NO}_{3}\right)_{3}$ Could Inhibit Growth of $V$. splendidus Vs

$\mathrm{Ga}\left(\mathrm{NO}_{3}\right)_{3}$ at concentrations of $20,40,80,160,320,640$, or $1,280 \mu \mathrm{M} \mathrm{Ga}\left(\mathrm{NO}_{3}\right)_{3}$ was tested for its ability to inhibit the growth of $V$. splendidus Vs at different time points. The inhibitory effect of $\mathrm{Ga}\left(\mathrm{NO}_{3}\right)_{3}$ on the growth of $V$. splendidus Vs was dose-dependent and time dependent. $\mathrm{Ga}\left(\mathrm{NO}_{3}\right)_{3}$ at concentrations higher than $160 \mu \mathrm{M}$ showed obvious inhibitory effects on the growth of $V$. splendidus Vs both at the exponential growth stage and with regard to the maximum biomass $\left(\mathrm{OD}_{600}\right)$. In the presence of 320,640 , or $1,280 \mu \mathrm{M} \mathrm{Ga}\left(\mathrm{NO}_{3}\right)_{3}$, the growth time needed to reach the maximum biomass was delayed for more than $12 \mathrm{~h}$, and the maximum biomass was also reduced to $80 \%, 81 \%$, or $66 \%$ of the control levels, respectively (Fig. 1A).

Compared with the inhibitory effect of $\mathrm{Ga}\left(\mathrm{NO}_{3}\right)_{3}$ in $2216 \mathrm{E}$ media, the inhibitory effect of $\mathrm{Ga}\left(\mathrm{NO}_{3}\right)_{3}$ in seawater was higher (Fig. 1B). After coincubation for $96 \mathrm{~h}$, the percentage of viable cells of $V$. splendidus Vs had decreased to $43.5 \%$ in the samples supplemented with $160 \mu \mathrm{M} \mathrm{Ga}\left(\mathrm{NO}_{3}\right)_{3}$. The viable cells of $V$. splendidus Vs decreased to $11.14 \%$ in the presence of $320 \mu \mathrm{M} \mathrm{Ga}\left(\mathrm{NO}_{3}\right)_{3}$. When the concentration of $\mathrm{Ga}\left(\mathrm{NO}_{3}\right)_{3}$ was increased to $640 \mu \mathrm{M}$, the percentage of viable $V$. splendidus Vs cells decreased to $0.2 \%$ (Fig. 1B).
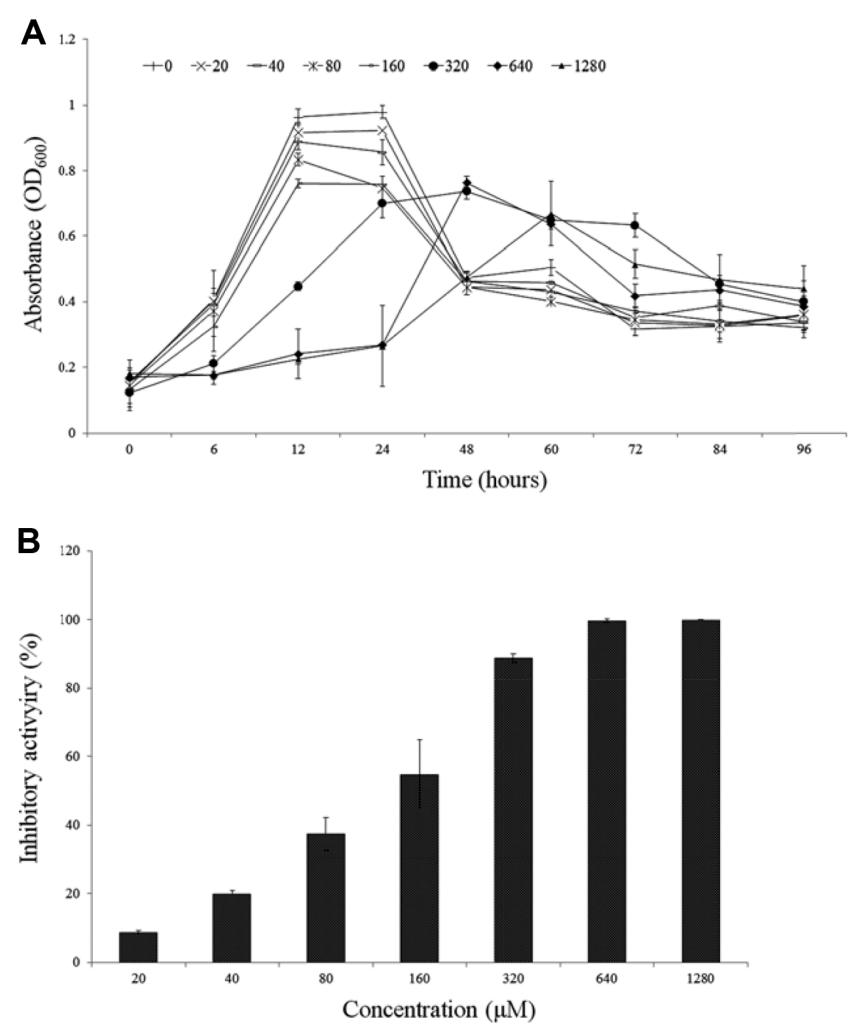

Fig. 1. (A) Growth curves of Vibrio splendidus $\mathrm{Vs}$ in the presence of $0,20,40,80,160,320,640$, and 1,280 $\mu \mathrm{M} \mathrm{Ga}\left(\mathrm{NO}_{3}\right)_{3}$. The bacteria were cultured at $28^{\circ} \mathrm{C}$, and culture samples at different time points were taken for measurement of $\mathrm{OD}_{600}$. (B) Inhibitory activity of $\mathrm{Ga}\left(\mathrm{NO}_{3}\right)_{3}$ on $\mathrm{V}$. splendidus $\mathrm{Vs}$ in the presence of $0,20,40,80,160,320,640$, and $1,280 \mu \mathrm{M} \mathrm{Ga}\left(\mathrm{NO}_{3}\right)_{3}$ in filter-sterilized seawater. After incubation at $28^{\circ} \mathrm{C}$ for $96 \mathrm{~h}$, the cultures were diluted 10 -fold, $100 \mu \mathrm{l}$ was spread onto solid $2216 \mathrm{E}$ media, and the bacterial colonies were counted after $24 \mathrm{~h}$ of incubation. The data are the means for at least three independent experiments and are presented as the mean $\pm \mathrm{SE}$.

\section{Effect of $\mathrm{Ga}\left(\mathrm{NO}_{3}\right)_{3}$ on Siderophore Production}

The growth of $V$. splendidus Vs was not inhibited by 20 or $40 \mu \mathrm{M} \mathrm{2,2}$-dipyridyl or $\mathrm{Ga}\left(\mathrm{NO}_{3}\right)_{3}$, but when the concentrations were higher, 2,2'-dipyridyl showed a stronger inhibitory effect than $\mathrm{Ga}\left(\mathrm{NO}_{3}\right)_{3}$ (Fig. 2A). In the presence of $160 \mu \mathrm{M} 2$, 2'-dipyridyl, the growth of $V$. splendidus Vs was only approximately half that in the presence of $160 \mu \mathrm{M} \mathrm{Ga}\left(\mathrm{NO}_{3}\right)_{3}$. A concentration of $320 \mu \mathrm{M} 2,2^{\prime}$-dipyridyl could nearly completely inhibit the growth of $V$. splendidus Vs, while $320 \mu \mathrm{M} \mathrm{Ga}\left(\mathrm{NO}_{3}\right)_{3}$ could only inhibit $10 \%$ of the growth. After measuring the growth, the siderophore production in the presence of 2,2'-dipyridyl or $\mathrm{Ga}\left(\mathrm{NO}_{3}\right)_{3}$ at different concentrations was determined. In the presence of 2,2'- 

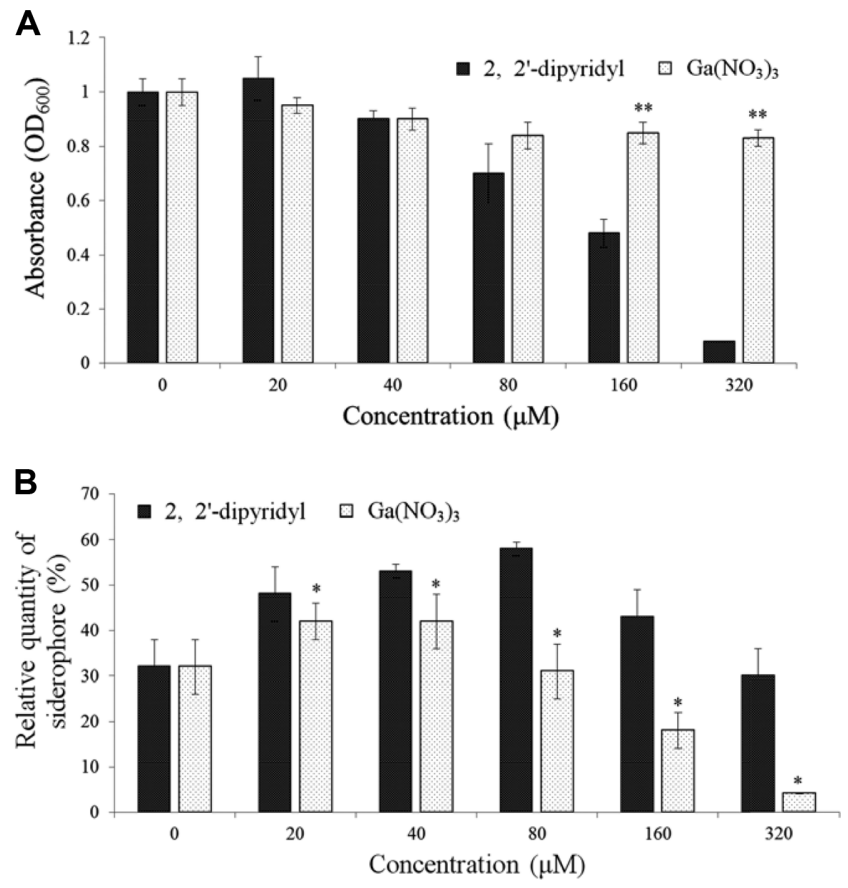

Fig. 2. (A) $\mathrm{OD}_{600}$ of $V$. splendidus $\mathrm{Vs}$ grown with different concentrations of 2,2'-dipyridyl or $\mathrm{Ga}\left(\mathrm{NO}_{3}\right)_{3}$. V. splendidus Vs was grown in the presence of $0,20,40,80,160$, and $320 \mu \mathrm{M}$ 2,2'-dipyridyl or the same concentrations of $\mathrm{Ga}\left(\mathrm{NO}_{3}\right)_{3}$ at $28^{\circ} \mathrm{C}$ for $48 \mathrm{~h}$, and then the $\mathrm{OD}_{600}$ was measured using a UV-Vis spectrophotometer. (B) Quantitative determination of siderophore production by $V$. splendidus Vs in the presence of 0,20 , $40,80,160$, and $320 \mu \mathrm{M} 2,2^{\prime}$-dipyridyl or the same concentrations of $\mathrm{Ga}\left(\mathrm{NO}_{3}\right)_{3}$ at $28^{\circ} \mathrm{C}$ for $48 \mathrm{~h}$. After incubation, the supernatants were collected for quantitative determination of siderophore production. The data are the means for at least three independent experiments and are presented as the mean $\pm \mathrm{SE}$. The relative quantities of siderophores produced by cells treated with $\mathrm{Ga}\left(\mathrm{NO}_{3}\right)_{3}$ were compared with those produced by cells treated with 2,2'-dipyridyl at each concentration. ${ }^{*} p<0.05$.

dipyridyl or $\mathrm{Ga}\left(\mathrm{NO}_{3}\right)_{3}$ at concentrations ranging from 20 to $160 \mu \mathrm{M}$, the relative siderophore production by $V$. splendidus Vs was significantly increased compared with that in the control group. However, the relative siderophore production in V. splendidus Vs supplemented with 2,2'-dipyridyl was higher than that in bacteria supplemented with the same concentration of $\mathrm{Ga}\left(\mathrm{NO}_{3}\right)_{3}$. The relative siderophore production was $57.6 \%$ in the presence of $80 \mu \mathrm{M} 2,2^{\prime}$ dipyridyl, while in the presence of $80 \mu \mathrm{M} \mathrm{Ga}\left(\mathrm{NO}_{3}\right)_{3}$, the siderophore production was $31.6 \%$, almost the same as in the control group. The relative siderophore production in

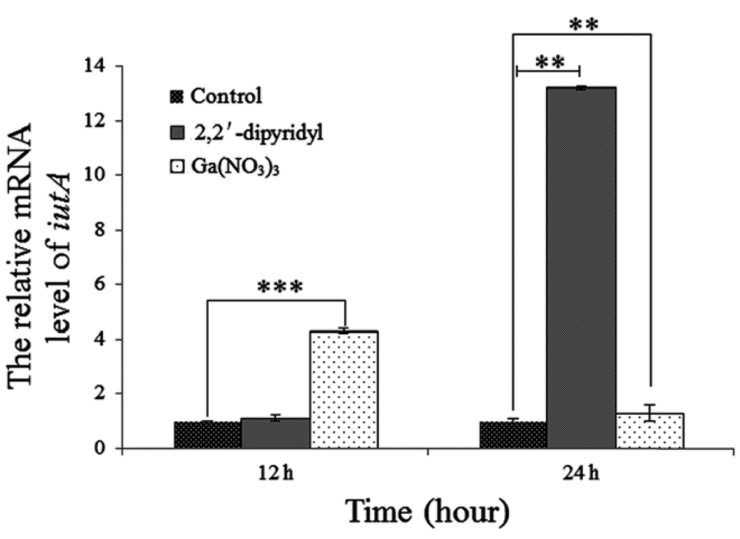

Fig. 3. The expression of the iutA gene in V. splendidus Vs at the mRNA level in the absence and presence of $\mathrm{Ga}\left(\mathrm{NO}_{3}\right)_{3}$ or 2,2'-dipyridyl.

The data are the means for at least three independent experiments and are presented as the mean $\pm \mathrm{SE}$. At each time point, the mRNA levels in cells treated with $\mathrm{Ga}\left(\mathrm{NO}_{3}\right)_{3}$ or 2,2'-dipyridyl were compared with those in cells without treatment. ${ }^{* *} p<0.001,{ }^{* *} p<0.01$, and ${ }^{*} p<0.05$.

the presence of $40 \mu \mathrm{M}, 80 \mu \mathrm{M}, 160 \mu \mathrm{M}$, or $320 \mu \mathrm{M} \mathrm{Ga}\left(\mathrm{NO}_{3}\right)_{3}$ was $75.9 \%, 51.2 \%, 41.3 \%$, or $13.3 \%$ of that in the presence of the corresponding concentration of 2,2'-dipyridyl, respectively (Fig. 2B). Combining the $\mathrm{OD}_{600}$ and siderophore production data, it could be concluded that there was less siderophore production in each individual cell in the presence of $\mathrm{Ga}\left(\mathrm{NO}_{3}\right)_{3}$ than in the presence of the same level of $2,2^{\prime}-$ dipyridyl.

\section{Effect of $\mathrm{Ga}\left(\mathrm{NO}_{3}\right)_{3}$ on Expression of iutA}

The expression of $i u t A$ was upregulated 4.3- and 1.3-fold at the mRNA level in cells cultured with $80 \mu \mathrm{M} \mathrm{Ga}\left(\mathrm{NO}_{3}\right)_{3}$ for $12 \mathrm{~h}$ and $24 \mathrm{~h}$, respectively, compared with control cells (Fig. 3). In cells treated with $80 \mu \mathrm{M} 2,2^{\prime}$-dipyridyl, the expression of iutA was upregulated 1.1- or 13.2-fold at the mRNA levels after $12 \mathrm{~h}$ or $24 \mathrm{~h}$ of incubation, respectively (Fig. 3). These results suggested that the addition of either $\mathrm{Ga}\left(\mathrm{NO}_{3}\right)_{3}$ or 2,2'-dipyridyl could upregulate the expression of iut $A$; however, the effect of $\mathrm{Ga}\left(\mathrm{NO}_{3}\right)_{3}$ was not as strong as that of the same amount of 2,2'-dipyridyl.

\section{V. splendidus Vs Produced HGA-Melanin That Promoted Growth at the Stationary Phase}

The absorbance spectrum and absorbance peak of HGAmelanin produced by $V$. splendidus Vs showed a maximum absorbance at $329 \mathrm{~nm}$ (data not shown). The growth of $V$. splendidus Vs declined after incubation for $24 \mathrm{~h}$; however, the HGA-melanin in the supernatant of $V$. splendidus Vs culture rapidly accumulated at this stage. After incubation 


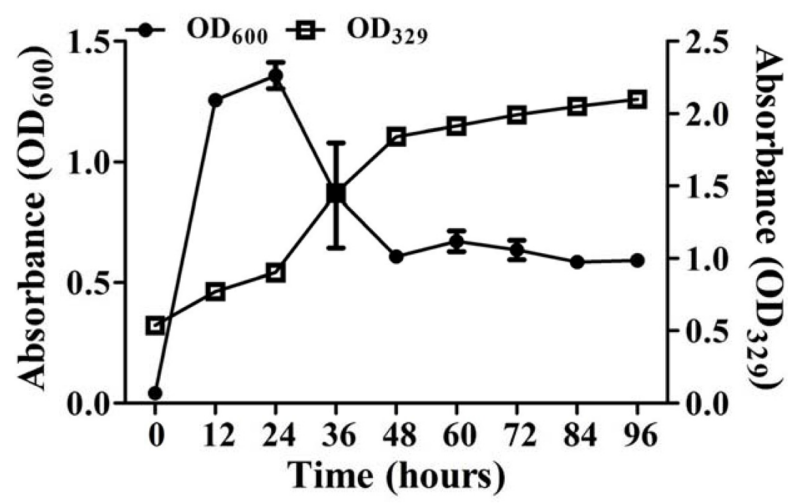

Fig. 4. Growth and HGA-melanin production of $V$. splendidus Vs. V. splendidus Vs in $2216 \mathrm{E}$ media containing $1.0 \mathrm{~g} / \mathrm{ml} \mathrm{L-}$ tyrosine was incubated at $28^{\circ} \mathrm{C}$.

The $\mathrm{OD}_{600}$ of $V$. splendidus Vs cultures and the $\mathrm{OD}_{329}$ of their cell-free supernatants were measured at $12-\mathrm{h}$ intervals for a total of $96 \mathrm{~h}$. The data are the means for at least three independent experiments and are presented as the mean \pm SE.

for $48 \mathrm{~h}$, the growth of $V$. splendidus Vs reached a stationary phase, and at this phase, the accumulation of HGAmelanin also tended to be stable (Fig. 4).

HGA-melanin was synthesized and used as a positive control for the HGA-melanin secreted by $V$. splendidus Vs. Pure monomeric HGA was used to generate HGA-melanin and then tested for its ability to reduce $\mathrm{Fe}^{3+}$ as a control.
Both synthetic HGA-melanin and pure monomeric HGA showed $\mathrm{Fe}^{3+}$ reduction activity acting as reducing agents of vitamin $\mathrm{C}$ and hydroxylamine hydrochloride, compared with the negative control (Fig. 5A). HGA-melanin extracted from the culture supernatant of $V$. splendidus $V s$ also showed obvious $\mathrm{Fe}^{3+}$ reduction activity (Fig. 5B). The $\mathrm{Fe}^{3+}$ reduction activity of natural HGA-melanin was similar to that of synthetic HGA-melanin. Taken together, the results indicated that $V$. splendidus Vs could synthetize HGAmelanin that could directly mediate $\mathrm{Fe}^{3+}$ reduction.

To determine whether HGA-melanin with $\mathrm{Fe}^{3+}$ reduction activity could promote the growth of $V$. splendidus Vs under iron-limited conditions, we applied the monomeric HGA and polymerized HGA-melanin to $2216 \mathrm{E}$ media supplemented with 8-hydroxyquinoline. The results showed that $V$. splendidus Vs cultured in 2216E media with 8hydroxyquinoline and HGA or with 8-hydroxyquinoline and HGA-melanin for $48 \mathrm{~h}$ exhibited $112.4 \%$ or $139.2 \%$ of the growth, respectively, of $V$. splendidus Vs cultured in 2216E media with 8-hydroxyquinoline alone (Fig. 6).

\section{$\mathrm{Ga}\left(\mathrm{NO}_{3}\right)_{3}$ Stimulated HGA-Melanin Production and the} Expression of feoA and feoB in V. splendidus Vs

HGA-melanin production by $V$. splendidus Vs significantly increased in the presence of $\mathrm{Ga}\left(\mathrm{NO}_{3}\right)_{3}$ and the increase occurred in a dose-dependent manner. The production of HGA-melanin in individual cells increased by 1.4-, 2.9-,
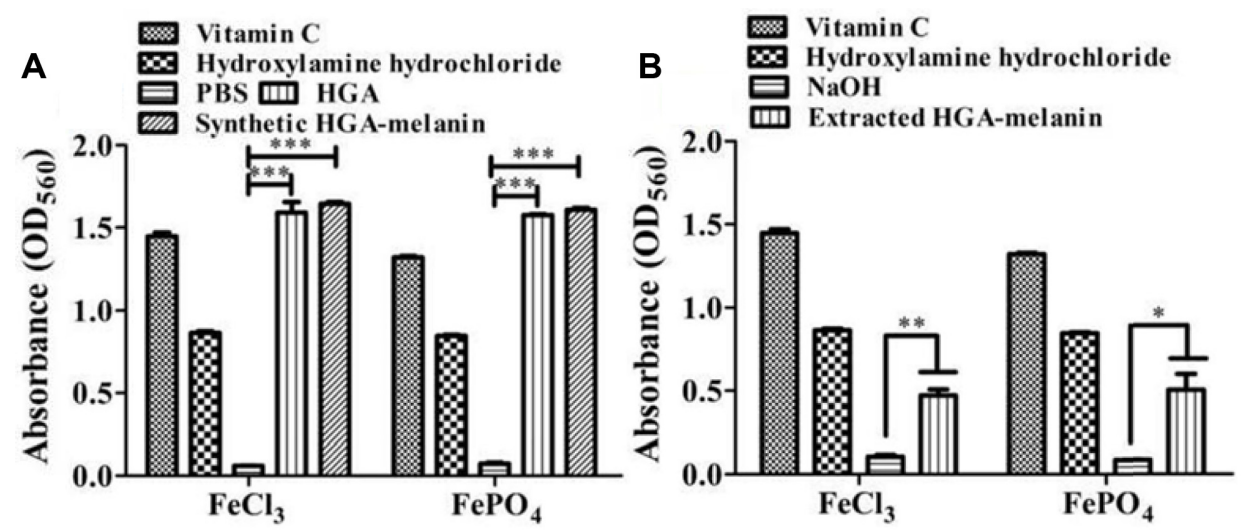

Fig. 5. (A) $\mathrm{Fe}^{3+}$ reduction by HGA or synthetic HGA-melanin. Vitamin $\mathrm{C}$ and hydroxylamine hydrochloride were used as positive controls, and PBS was used as a negative control. (B) $\mathrm{Fe}^{3+}$ reduction by extracted HGA-melanin. Acid-precipitated HGA-melanin obtained from the culture supernatants of $V$. splendidus $\mathrm{Vs}$ was mixed with $\mathrm{FeCl}_{3}$. $\mathrm{NaOH}$ was used as a negative control for the extracted HGA-melanin. Vitamin C or hydroxylamine hydrochloride was used as a positive control. The reactions were allowed to proceed at room temperature for $12 \mathrm{~h}$. The changes in color associated with ferrozine binding to $\mathrm{Fe}^{2+}$ were measured. The data are the means for at least three independent experiments and are presented as the mean $\pm \mathrm{SE}$. Comparisons were made between the $\mathrm{OD}_{560}$ values of the reactions catalyzed by HGA, synthetic HGA-melanin, or extracted HGA-melanin and the corresponding negative control values. ${ }^{* *} p<0.001,{ }^{* *} p<0.01$, and ${ }^{*} p<0.05$. 


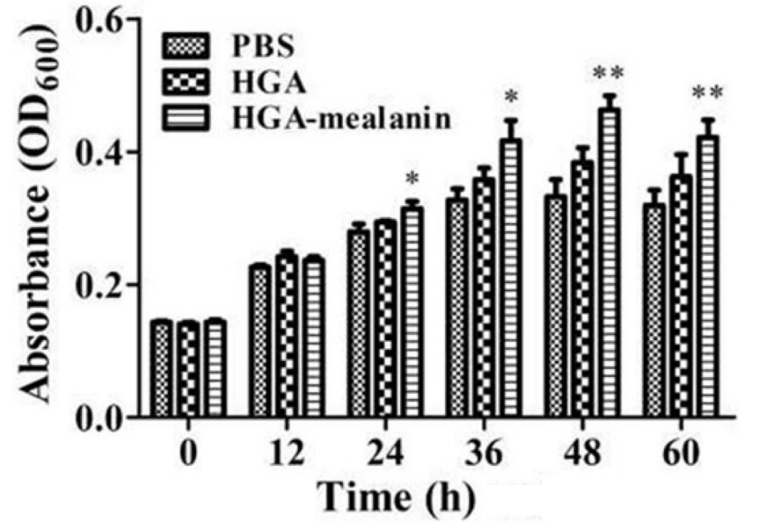

Fig. 6. $\mathrm{OD}_{600}$ of $V$. splendidus Vs in the presence of HGA or HGA-melanin at different time points.

PBS was used as a negative control for HGA and HGA-melanin. The data are the means for at least three independent experiments and are presented as the mean $\pm \mathrm{SE}$. At each time point, the $\mathrm{OD}_{600}$ values of cultures with HGA or HGA-melanin were compared with those of cultures without treatment. ${ }^{* *} p<0.01,{ }^{*} p<0.05$.

and 4.8-fold, when $V$. splendidus Vs was grown in $2216 \mathrm{E}$ media in the presence of $320 \mu \mathrm{M}, 640 \mu \mathrm{M}$, or $1,280 \mu \mathrm{M}$ $\mathrm{Ga}\left(\mathrm{NO}_{3}\right)_{3}$, respectively (Fig. 7).

It is clear from the above data that in the presence of $\mathrm{Ga}\left(\mathrm{NO}_{3}\right)_{3}, V$. splendidus Vs could stimulate the production of HGA-melanin, an $\mathrm{Fe}^{3+}$-reducing regent, to promote its own growth. Feo $A$ and $f e o B$ are two genes encoding proteins that facilitate the transportation of $\mathrm{Fe}^{2+}$ into cells. The expression of $f e o A$ was upregulated 1.9- and 1.4-fold at the mRNA level in cells treated with HGA-melanin for $1 \mathrm{~h}$ and $24 \mathrm{~h}$ respectively (Fig. $8 \mathrm{~A}$ ). Under the same conditions, the mRNA level of $f e o B$ was upregulated 2.1- and 6.1-fold

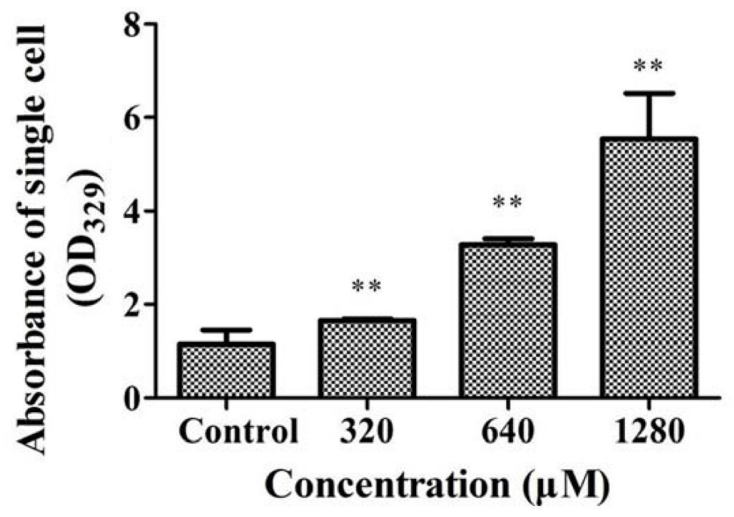

Fig. 7. $\mathrm{OD}_{329}$ values of cell-free supernatants from $V$. splendidus Vs cultures in the presence of different concentrations of $\mathrm{Ga}\left(\mathrm{NO}_{3}\right)_{3}$.

The $\mathrm{OD}_{329}$ of the cell-free supernatant from a V. splendidus Vs culture grown without $\mathrm{Ga}\left(\mathrm{NO}_{3}\right)_{3}$ was used as a control. The data are the means for at least three independent experiments and are presented as the mean $\pm \mathrm{SE}$. At each time point, the $\mathrm{OD}_{329}$ of the culture with $\mathrm{Ga}\left(\mathrm{NO}_{3}\right)_{3}$ was compared with that of the culture without treatment. ${ }^{* *} p<0.01,{ }^{*} p<0.05$.

at $1 \mathrm{~h}$ and $24 \mathrm{~h}$, respectively (Fig. $8 \mathrm{~B}$ ). The expression of $f e o A$ and $f e o B$ was also upregulated at the mRNA level in cells treated with $640 \mu \mathrm{M} \mathrm{Ga}\left(\mathrm{NO}_{3}\right)_{3}$. The expression of $f e o A$ and $f e o B$ was upregulated 4.1- and 2.7-fold after treatment for $30 \mathrm{~min}$, respectively (Fig. 9B).

\section{Discussion}

$V$. splendidus is an opportunistic pathogen that causes severe mortality and morbidity in its hosts [28]. In our previous study, the iron uptake process was determined to
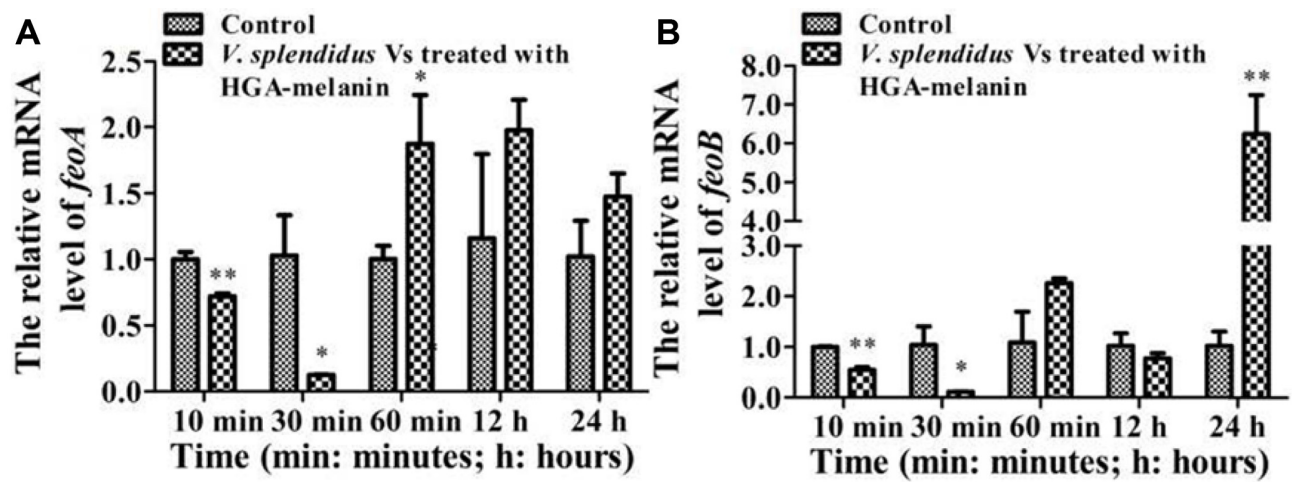

Fig. 8. (A) Expression of $f e o A$ at the mRNA level in the presence of HGA-melanin. (B) Expression of $f e o B$ at the mRNA level in the presence of HGA-melanin. The data are the means for at least three independent experiments and are presented as the mean \pm SE. At each time point, the mRNA levels in the cells treated with HGA-melanin were compared with those in the cells without treatment. ${ }^{* *} p<0.01,{ }^{*} p<0.05$. 

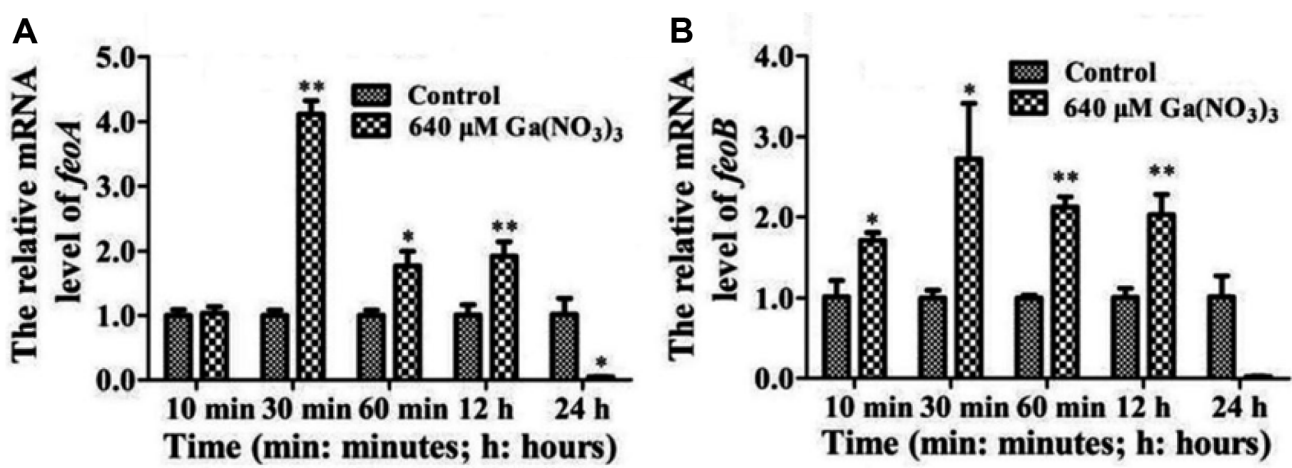

Fig. 9. (A) The expression of $f e o A$ at the mRNA level in the presence of $\mathrm{Ga}\left(\mathrm{NO}_{3}\right)_{3}$. (B) The expression of $f e o B$ at the mRNA level in the presence of $\mathrm{Ga}\left(\mathrm{NO}_{3}\right)_{3}$. The data are the means for at least three independent experiments and are presented as the mean $\pm \mathrm{SE}$. At each time point, the mRNA levels in the cells treated with $\mathrm{Ga}\left(\mathrm{NO}_{3}\right)_{3}$ were compared with those in the cells without treatment. ${ }^{* *} p<0.01,{ }^{*} p<0.05$.

be associated with the pathogenesis of $V$. splendidus Vs [13]. One of the iron uptake pathways in V. splendidus Vs involves the use of $\mathrm{Fe}^{3+}$ via a hydroxamic siderophoreIutA-receptor, as proposed in our previous study [14]. $\mathrm{Ga}^{3+}$ has a similar radius as $\mathrm{Fe}^{3+}$, and it could compete with $\mathrm{Fe}^{3+}$ for binding to biomacromolecules that need $\mathrm{Fe}^{3+}$ in biologic systems [29]. Thus, $\mathrm{Ga}^{3+}$ has been used as an anti-infective agent in Pseudomonas aeruginosa [30], Staphylococcus aureus [31], Acinetobacter baumannii [32] and Rhodococcus equi [33]. In our present study, the potential of $\mathrm{Ga}\left(\mathrm{NO}_{3}\right)_{3}$ to be used as an antibacterial substance to repress $V$. splendidus Vs was determined. $\mathrm{Ga}\left(\mathrm{NO}_{3}\right)_{3}$ inhibited the growth of $V$. splendidus $\mathrm{Vs}$, especially in an oligotrophic environment under iron deficiency. However, the inhibitory effect of $\mathrm{Ga}\left(\mathrm{NO}_{3}\right)_{3}$ on $V$. splendidus Vs was not as strong as that on A. baumannii [32], Mycobacterium avium subsp. paratuberculosis (MAP) [34], Mycobacterium tuberculosis [35], Klebsiella pneumonia [36] E. coli, and Enterococcus faecalis [37]. Moreover, the inhibitory effect of $\mathrm{Ga}\left(\mathrm{NO}_{3}\right)_{3}$ on the growth of $V$. splendidus Vs decreased when $V$. splendidus Vs was cultured to the stationary phase. This led us to wonder if there were other iron uptake pathways in $V$. splendidus Vs that could not be suppressed by $\mathrm{Ga}\left(\mathrm{NO}_{3}\right)_{3}$.

Although $\mathrm{Ga}\left(\mathrm{NO}_{3}\right)_{3}$ or 2,2'-dipyridyl could increase the production of siderophores, the increase caused by $\mathrm{Ga}\left(\mathrm{NO}_{3}\right)_{3}$ was smaller than that caused by 2,2'-dipyridyl. In view of this, $\mathrm{Ga}^{3+}$ may compete with $\mathrm{Fe}^{3+}$ for binding to the siderophores produced by $V$. splendidus $V$ s given that siderophores could chelate $\mathrm{Ga}^{3+}$ instead of $\mathrm{Fe}^{3+}$, as proposed previously [21]. The addition of $\mathrm{Ga}\left(\mathrm{NO}_{3}\right)_{3}$ or 2,2'-dipyridyl could upregulate the expression of $i u t A$, but the upregulation caused by $\mathrm{Ga}\left(\mathrm{NO}_{3}\right)_{3}$ was smaller than that caused by the same level of 2,2'-dipyridyl. This result suggested that $\mathrm{Ga}^{3+}$ might attenuate the $\mathrm{Fe}^{3+}$ absorption pathway mediated by the hydroxamic siderophore-IutA-receptor in $V$. splendidus Vs. Our result is consistent with previous reports that $\mathrm{Ga}^{3+}$ mimics $\mathrm{Fe}^{3+}$ and further affects the $\mathrm{Fe}^{3+}$ absorption pathway mediated by siderophores [38, 39].

HGA-melanin produced from the catabolism of tyrosine via $p$-hydroxyphenylpyruvate (HPP) and homogentisic acid (HGA) has been reported in P. aeruginosa [40, 41], Shewanella colwelliana [42], Alcaligenes eutrophus CH34 [43], Burkholderia cepacia [44] and L. pneumophila [45]. HGAmelanin is a multifunctional polymer that can facilitate bacterial growth, partly due to its ability to reduce $\mathrm{Fe}^{3+}$. The $\mathrm{Fe}^{3+}$ reduction activity of HGA-melanin has been demonstrated in L. pneumophila [45] and Shewanella algae [46, 47]. Our results showed that $V$. splendidus Vs could produce HGAmelanin which possessed $\mathrm{Fe}^{3+}$ reduction activity, and that HGA-melanin could promote the growth of V. splendidus Vs under iron-limited conditions. These findings are consistent with findings regarding the HGA-melanin produced by L. pneumophila which mediated $\mathrm{Fe}^{3+}$ reduction, and thus increasing $\mathrm{Fe}^{2+}$ availability to bacterial cells with the help of FeoA and FeoB, members of Feo transporter system for specific acquisition of $\mathrm{Fe}^{2+}$ from the external environment [10, 12, 48, 49]. Our results are the first to reveal the pathway of $\mathrm{Fe}^{2+}$ uptake mediated by HGAmelanin in $V$. splendidus Vs.

Although $\mathrm{Ga}\left(\mathrm{NO}_{3}\right)_{3}$ could repress $\mathrm{Fe}^{3+}$ uptake [38, 39], $\mathrm{Ga}\left(\mathrm{NO}_{3}\right)_{3}$ also showed a stimulatory effect on the HGAmelanin-mediated $\mathrm{Fe}^{2+}$ uptake pathway in the current study. In the presence of $\mathrm{Ga}\left(\mathrm{NO}_{3}\right)_{3}$, both HGA-melanin production and the expression of $f e o A$ and $f e o B$, were 
upregulated. The increase in the expression of $f e o A$ and $f e o B$ in the presence of $\mathrm{Ga}\left(\mathrm{NO}_{3}\right)_{3}$ occurred earlier than that in the presence of exogenously added HGA-melanin. The difference in the response time may have been due to the different actions of the two chemicals: HGA-melanin, as an $\mathrm{Fe}^{2+}$ reducing reagent, may have functioned much later than $\mathrm{Ga}\left(\mathrm{NO}_{3}\right)_{3}$, an $\mathrm{Fe}^{3+}$ chelator. When $\mathrm{Ga}\left(\mathrm{NO}_{3}\right)_{3}$ was added, $\mathrm{Ga}^{3+}$ could enter the cells instead of $\mathrm{Fe}^{3+}$, causing the cells to sense that they were under iron-limited conditions. Under these conditions, the ferric uptake regulator (Fur) could function and regulate the related expression [50]. In Streptococcus suis and Vibrio cholera, Fur has been reported to negatively regulate the feo system [51,52]. Combined, all the data suggested that in the presence of $\mathrm{Ga}\left(\mathrm{NO}_{3}\right)$, the growth of $V$. splendidus $V s$ was inhibited due to the replacement of $\mathrm{Fe}^{3+}$ by $\mathrm{Ga}^{3+}$, while the $\mathrm{Fe}^{2+}$ uptake pathway mediated by HGA-melanin was stimulated to compensate for growth. However, the stimulated $\mathrm{Fe}^{2+}$ uptake pathway could not completely compensate for the damaged $\mathrm{Fe}^{3+}$ uptake pathway, so the combined effect of $\mathrm{Ga}\left(\mathrm{NO}_{3}\right)_{3}$ involved a decrease in the maximum $\mathrm{OD}_{600}$ and a delay of the stationary phase. The inhibitory effect of $\mathrm{Ga}\left(\mathrm{NO}_{3}\right)_{3}$ on the growth of $V$. splendidus Vs was weaker in the 2216E media than in seawater. Therefore, $\mathrm{Ga}\left(\mathrm{NO}_{3}\right)_{3}$ shows promising potential for use in preventing disease in $A$. japonicus infected with $V$. splendidus Vs in aquaculture.

\section{Acknowledgments}

This work was financially supported by the National Natural Science Foundation of China (41676141 and 41576139), the Ningbo Science and Technology Development Plan (2015C50057), and the K.C. Wong Magna Fund at Ningbo University.

\section{Conflict of Interest}

The authors have no financial conflicts of interest to declare.

\section{References}

1. Han QX, Keesing JK, Liu DY. 2016. A review of sea cucumber aquaculture, ranching, and stock enhancement in China. Rev. Fish. Sci. Aquac. 24: 326-341.

2. Li Z, Zhang JC, Li X, Wang XY, Cao ZH, Wang LL, Xu YP. 2016. Efficiency of a bacteriophage in controlling vibrio infection in the juvenile sea cucumber Apostichopus japonicus. Aquac. 451: 345-352.
3. Zhang CY, Wang YG, Rong XJ. 2006. Isolation and identification of causative pathogen for skin ulcerative syndrome in Apostichopus japonicus. J. Fish. Sci. China 30: 118-123.

4. Kirchman DL, Meon B, Cottrell MT, Hutchins DA, Weeks D, Bruland KW. 2000. Carbon versus iron limitation of bacterial growth in the California upwelling regime. Limnol. Oceanogr. 45: 1681-1688.

5. Larson JA, Higashi DL, Stojiljkovic I, So M. 2002. Replication of Neisseria meningitidis within epithelial cells requires TonB-dependent acquisition of host cell iron. Infect. Immun. 70: 1461-1467.

6. Sritharan M. 2000. Iron as a candidate in virulence and pathogenesis in mycobacteria and other microorganisms. World. J. Microiol. Biotechnol. 16: 769-780.

7. Raymond KN, Carrano CJ. 1979. Coordination chemistry and microbial iron transport. Accounts Chem. Res. 12: 183-190.

8. Wandersman C, Delepelaire P. 2004. Bacterial iron sources: from siderophores to hemophores. Annu. Rev. Microbiol. 58: 611-647.

9. Méndez P, Pérez-Pascual R, Gómez D, Guijarro JA. 2012. An overview of virulence-associated factors of gram-negative fish pathogenic bacteria. Health. Environ. 5: 133-156.

10. Cartron ML, Maddocks S, Gillingham P, Craven CJ, Andrews SC. 2006. Feo--transport of ferrous iron into bacteria. Biometals 19: 143-157.

11. Robey M, Cianciotto NP. 2002. Legionella pneumophila feoAB promotes ferrous iron uptake and intracellular infection. Infect. Immun. 70: 5659-5669.

12. Zheng HX, Chatfield CH, Liles MR, Cianciotto NP. 2013. Secreted pyomelanin of Legionella pneumophila promotes bacterial iron uptake and growth under iron-limiting conditions. Infect. Immun. 81: 4182-4191.

13. Zhang WW, Liang WK, Li CH. 2016. Inhibition of marine Vibrio sp. by pyoverdine from Pseudomonas aeruginosa PA1. J. Hazard. Mater. 302: 217-224.

14. Song TX, Liu HJ, Lv TT, Zhao XL, Shao YN, Han QX, et al. 2018. Characteristics of the iron uptake-related process of a pathogenic Vibrio splendidus strain associated with massive mortalities of the sea cucumber Apostichopus japonicus. J. Invertebr. Pathol. 155: 25-31.

15. Ross-Gillespie A, Weigert M, Brown SP, Kümmerli R. 2014 Gallium-mediated siderophore quenching as an evolutionarily robust antibacterial treatment. Evol. Med. Public Health 1: 18-19.

16. Rodriguez GM, Gardner R, Kaur N, Phanstiel IVO. 2008. Utilization of $\mathrm{Fe}^{3+}$-acinetoferrin analogs as an iron source by Mycobacterium tuberculosis. Biometals 21: 93-103.

17. Stojiljkovic I, Kumar V, Srinivasan N. 1999. Non-iron metalloporphyrins: potent antibacterial compounds that exploit haem $/ \mathrm{Hb}$ uptake systems of pathogenic bacteria Mol. Microbiol. 31: 429-442. 
18. Minandri F, Bonchi C, Frangipani E, Imperi F, Visca P. 2014. Promises and failures of gallium as an antibacterial agent. Future Microbiol. 9: 379-397.

19. Kaneko Y, Thoendel M, Olakanmi O, Britiganet BE, Singh PK. 2007. The transition metal gallium disrupts Pseudomonas aeruginosa iron metabolism and has antimicrobial and antibiofilm activity. J. Clin. Invest. 117: 877-888.

20. Deleon K, Balldin F, Watters C, Hamood A, Griswold J, Sreedharan S, et al. 2009. Gallium maltolate treatment eradicates Pseudomonas aeruginosa infection in thermally injured mice. Antimicrob. Agents Chemother. 53: 1331-1337.

21. Chitambar CR. 2016. Gallium and its competing roles with iron in biological systems. Biochim. Biophys. Acta 1863: 20442053.

22. Schwyn B, Neilands JB. 1987. Universal chemical assay for the detection and determination of siderophores. Anal. Biochem. 160: 47-56.

23. Payne SM. 1994. Detection, isolation, and characterization of siderophores, Methods Enzymol. 235: 329-344.

24. Zhu S, Lu Y, Xu X, Chen J, Yang J, Ma X. 2015. Isolation and identification of a gene encoding 4-hydroxyphenylpyruvate dioxygenase from the red-brown pigment-producing bacterium Alteromonas stellipolaris LMG 21856. Folia Microbiol. 60: 1-8.

25. Chatfield CH, Cianciotto NP. 2007. The secreted pyomelanin pigment of Legionella pneumophila confers ferric reductase activity. Infect. Immun. 75: 4062-4070.

26. Brewster JD. 2003. A simple micro-growth assay for enumerating bacteria. J. Microbiol. Methods 53: 77-86.

27. Zhang WW, Sun K, Cheng S, Sun L. 2008. Characterization of $D e g Q_{V h}$, a serine protease and a protective immunogen from a pathogenic Vibrio harveyi strain. Appl. Environ. Microbiol. 74: 6254-6262.

28. Torresi M, Acciari VA, Piano A, Serratore P, Prencipe V, Migliorati G. 2011. Detection of Vibrio splendidus and related species in Chamelea gallina sampled in the Adriatic along the Abruzzi coastline. Vet. Ital. 47: 371-378.

29. Olakanmi O, Britigan BE, Schlesinger LS. 2000. Gallium disrupts iron metabolism of mycobacteria residing within human macrophages. Infect. Immun. 68: 5619-5627.

30. Banin E, Lozinski A, Brady KM, Berenshtein E, Butterfield PW, Moshe M, et al. 2008. The potential of desferrioxaminegallium as an anti-pseudomonas therapeutic agent. Proc. Natl. Acad. Sci. USA 105: 16761-6766.

31. Menon S, Jr WH, Tsan MF. 1978. Studies on gallium accumulation in inflammatory lesions: II. Uptake by Staphylococcus aureus: concise communication. J. Nucl. Med. 19: 44-47.

32. Antunes LCS, Imperi F, Minandri F, Visca P. 2012. In vitro and in vivo antimicrobial activities of gallium nitrate against multidrug-resistant Acinetobacter baumannii. Antimicrob. Agents Chemother. 56: 5961-5970.
33. Harrington JR, Martens RJ, Cohen ND, Bernstein LR. 2006. Antimicrobial activity of gallium against virulent Rhodococcus equiin vitro and in vivo. J. Vet. Pharmacol. Ther. 29: 121-127.

34. Fecteau ME, Aceto HW, Bernstein LR, Sweeney RW. 2014. Comparison of the antimicrobial activities of gallium nitrate and gallium maltolate against Mycobacterium avium subsp. paratuberculosis in vitro. Vet. J. 202: 195-197.

35. Oyebode Olakanmi, Banurekha Kesavalu, Rajamouli Pasula, et al. Gallium nitrate is efficacious in murine models of tuberculosis and inhibits key bacterial Fe-dependent enzymes. Antimicrob. Agents Chemother. 57: 6074-6080.

36. Mitchell G. Thompson, Vu Truong-Le, Yonas A. Alamneh. 2015. Evaluation of gallium citrate formulations against a multidrug-resistant strain of Klebsiella pneumoniae in a murine wound model of infection. Antimicrob. Agents Chemother. 59: 6484-6493.

37. Xu ZR, Zhao X, Chen XD, Chen Z, Xia ZF. 2017. Antimicrobial effect of gallium nitrate against bacteria encountered in burn wound infections. Rsc. Adv. 7: 52266-52273.

38. Emery T. 1971. Role of ferrichrome as a ferric ionophore in Ustilago sphaerogena. Biochemistry 10: 1483-1488.

39. Leong J, Neilands JB, Raymond KN. 1974. Coordination isomers of biological iron transport compounds III. (1) Transport of $\lambda$-cis-chromic desferriferrichrome by Ustilago sphaerogena. Biochem. Biophys. Res. Commun. 60: 1066-1071.

40. Yabuuchi E, Omyama A. 1972. Characterization of "pyomelanin"-producing strains of Pseudomonas aeruginosa. Int. J. Syst. Bacteriol. 22: 53-64.

41. Ogunnariwo J, Hamiltonmiller JM. 1975. Brown- and redpigmented Pseudomonas aeruginosa: differentiation between melanin and pyorubrin. J. Med. Microbiol. 8: 199-203.

42. Coon SL, Kotob S, Jarvis BB, Fuqua WC, Weiner RM. 1994. Homogentisic acid is the product of MelA, which mediates melanogenesis in the marine bacterium Shewanella colwelliana D. Appl. Environ. Microbiol. 60: 3006-3010.

43. David C, Daro A, Szalai E, Atarhouch T, Mergeay M. 1996. Formation of polymeric pigments in the presence of bacteria and comparison with chemical oxidative coupling-II. Catabolism of tyrosine and hydroxyphenylacetic acid by Alcaligenes eutrophus $\mathrm{CH} 34$ and mutants. Eur. Polym. J. 32: 669-697.

44. Zughaier SM, Ryley HC, Jackson SK. 1999. A melanin pigment purified from an epidemic strain of Burkholderia cepacia attenuates monocyte respiratory burst activity by scavenging superoxide anion. Infect. Immun. 67: 908-913.

45. Steinert M, Flügel M, Schuppler M, Helbig JH, Supriyono A, Proksch P, et al. 2001. The Lly protein is essential for p-hydroxyphenylpyruvate dioxygenase activity in Legionella pneumophila. FEMS. Microbiol. Lett. 203: 41-47.

46. Turick CE, Beliaev AS, Zakrajsek BA, Reardon CL, Lowy DA, Poppy TE, et al. 2009. The role of 4-hydroxyphenylpyruvate dioxygenase in enhancement of solid-phase electron transfer 
by Shewanella oneidensis MR-1. FEMS. Microbiol. Ecol. 68: 223235.

47. Turick CE, Jr CF, Tisa LS. 2008. Pyomelanin is produced by Shewanella algae BrY and affected by exogenous iron. Can. J. Microbiol. 54: 334-339.

48. Stojiljkovic I, Cobeljic M, Hantke K. 1993. Escherichia coli K12 ferrous iron uptake mutants are impaired in their ability to colonize the mouse intestine. FEMS. Microbiol. Lett. 108: 111-115.

49. Tsolis RM, Baumler AJ, Heffron F, Stojiljkovic I. 1996. Contribution of TonB- and Feo-mediated iron uptake to growth of Salmonella typhimurium in the mouse. Infect. Immun. 64: 4549-4556.

50. Troxell B, Hassan HM. 2013. Transcriptional regulation by Ferric Uptake Regulator (Fur) in pathogenic bacteria. Front. Cell Infect. Microbiol. 3: 59.

51. Mey AR, Wyckoff EE, Vanamala K, Fisher CR, Payne SM. 2005. Iron and fur regulation in Vibrio cholerae and the role of fur in virulence. Infect. Immun. 73: 8167-8178.

52. Aranda J, Cortés P, Garrido ME, Fittipaldi N, Llagostera M, Gottschalk M, et al. 2009. Contribution of the FeoB transporter to Streptococcus suis virulence. Int. Microbiol. 12: 137-143. 